\title{
Soil fertility and upland rice yield after biochar application in the Cerrado
}

\author{
Fabiano André Petter(1), Beáta Emöke Madari(2), Mellissa Ananias Soler da Silva(2), Marco Aurélio Carbone Carneiro(3), \\ Márcia Thaís de Melo Carvalho ${ }^{(4)}$, Ben Hur Marimon Júnior ${ }^{(5)}$ and Leandro Pereira Pacheco(1)
}

\begin{abstract}
(1)Universidade Federal do Piauí, Departamento de Agronomia, Campus Professora Cinobelina Elvas, CEP 64900-000 Bom Jesus, PI, Brazil. E-mail: petter@ufpi.edu.br, leandroppacheco@gmail.com ${ }^{(2)}$ Embrapa Arroz e Feijão, Caixa Postal 179, CEP 75375-000 Santo Antônio de Goiás, GO, Brazil. E-mail: madari@cnpaf.embrapa.br, melsoler@gmail.com ${ }^{(3)}$ Universidade Federal de Goiás, Campus Samambaia, Caixa Postal 131, CEP 74690-900 Goiânia, GO, Brazil. E-mail: carbonecarneiro@yahoo.com.br ${ }^{(4)}$ Embrapa Arroz e Feijão/Centre for Crop Systems Analysis, University of Wageningen, Post Office Box 430, 6700 AK Wageningen, The Netherlands, E-mail: marcia@cnpaf.embrapa.br (5) Universidade Estadual de Mato Grosso, Departamento de Biologia, Campus de Nova Xavantina, Caixa Postal 08, CEP 78690-000 Nova Xavantina, MT, Brazil. E-mail: bhmjunior@gmail.com
\end{abstract}

\begin{abstract}
The objective of this work was to evaluate the effect of biochar made from Eucalyptus on soil fertility, and on the yield and development of upland rice. The experiment was performed during two years in a randomized block design with four replicates, in a sandy loam Dystric Plinthosol. Four doses of NPK $05-25-15$, annually distributed in stripes $\left(0,100,200\right.$ and $\left.300 \mathrm{~kg} \mathrm{ha}^{-1}\right)$, and four doses of biochar $(0,8,16$ and $32 \mathrm{Mg} \mathrm{ha}^{-1}$ ), applied once in the first year - alone or with NPK - were evaluated. In the first year, biochar positively affected soil fertility [total organic carbon (TOC), $\mathrm{Ca}, \mathrm{P}, \mathrm{Al}, \mathrm{H}+\mathrm{Al}$, and $\mathrm{pH}$ ], at $0-10 \mathrm{~cm}$ soil depth, and it was the only factor with significant effect on yield. In the second year, the effect of biochar diminished or was overcome by the fertilizer. TOC moved down in the soil profile to the $0-20 \mathrm{~cm}$ depth, influencing $\mathrm{K}$ availability in this layer. In the second year, there was a significant interaction between biochar and the fertilizer on plant growth and biomass dry matter accumulation.
\end{abstract}

Index terms: biochar, macronutrients, plant biomass, plant growth, soil acidity, rice yield.

\section{Fertilidade do solo e produtividade do arroz de terras altas no Cerrado após aplicação de "biochar"}

Resumo - O objetivo deste trabalho foi avaliar o efeito do "biochar" de Eucalyptus sobre a fertilidade do solo, e sobre a produtividade e o desenvolvimento do arroz de terras altas. O experimento foi conduzido durante dois anos, em delineamento de blocos ao acaso, com quatro repetições, em Plintossolo Háplico franco-arenoso. Foram avaliadas quatro doses do fertilizante mineral NPK 05-25-15 $\left(0,100,200\right.$ e $\left.300 \mathrm{~kg} \mathrm{ha}^{-1}\right)$, distribuídas anualmente em faixas, e quatro doses de "biochar" $\left(0,8,16\right.$ e $\left.32 \mathrm{Mg} \mathrm{ha}^{-1}\right)$, aplicadas uma única vez, no primeiro ano, sozinho ou com o fertilizante. No primeiro ano, o "biochar" afetou positivamente a fertilidade do solo [carbono orgânico total (TOC), $\mathrm{Ca}, \mathrm{P}, \mathrm{Al}, \mathrm{H}+\mathrm{Al}$ e pH], à profundidade de $0-10 \mathrm{~cm}$, e foi o único fator com efeito significativo sobre a produtividade. No segundo ano, o efeito do "biochar" diminuiu ou foi superado pelo do fertilizante. O TOC se movimentou no perfil do solo para a profundidade de 10-20 cm, e isto influenciou a disponibilidade de K naquela camada. No segundo ano, houve interação significativa entre "biochar" e fertilizante quanto ao crescimento das plantas e ao acúmulo de massa de matéria seca.

Termos para indexação: "biochar", macronutrientes, fitomassa, crescimento de planta, acidez do solo, produtividade do arroz.

\section{Introduction}

The Cerrado soils are generally acid and feature low-natural fertility with low-available $\mathrm{P}, \mathrm{K}$, and cation exchange capacity (CEC), and high-aluminum saturation (Fageria \& Souza, 1995). Also, dry periods frequently occur during the growing season. In these conditions, upland rice production is considered an activity at risk.
Increasing soil organic matter (SOM) content generally improves soil chemical, physical, and biological properties, and increases nutrient recycling (Crusciol et al., 2005; Torres et al., 2005; Boer et al., 2007; Carpim et al., 2008). No-tillage with crop rotation systems are relevant practices to raise SOM levels, at least at the top soil layers (Barreto et al., 2009). However, for upland rice, these management systems 
have often lead to frustrations, due to the weak initial vigor of plants (Santos et al., 1997).

Recently, new form of use for pyrolysis byproducts has been proposed as soil amendment (biochar), to enhance soil properties, hence aggregating value to them. Biochar has beneficial effects on the chemical, physical and biological soil properties, besides contributing to enhance crop biomass and yield (Glaser et al., 2002; Kookana et al., 2011).

According to Madari et al. (2006), based on experiments in pots, upland rice is positively affected by eucalyptus charcoal addition to the soil. According to these authors, upland rice had a better initial vigor and biomass accumulation, a more uniform development, and larger seed dry mass. The application of biochar also enhanced soil properties, reducing potential acidity and increasing available $\mathrm{P}$ and $\mathrm{K}$.

The objective of this work was to evaluate the effect of biochar made from Eucalyptus, in a sole application or in combination with mineral fertilizer, on soil fertility and on yield and development of upland rice.

\section{Materials and Methods}

The field experiment was implemented in Nova Xavantina, MT, Brazil, in the Cerrado biome (14 $34^{\prime} 50^{\prime \prime} \mathrm{S}, 52^{\circ} 24^{\prime} 01^{\prime \prime} \mathrm{W}$, at $310 \mathrm{~m}$ altitude), in November 2008. The soil was a Dystric Plinthosol (Nachtergaele, 2005). Before experiment implementation, the area was used as degraded pasture. The dominant species was Urochloa ruziziensis.

Data of rainfall distribution and temperature during the growing period of the rice are presented in Figure 1.

The NPK 05-25-15 doses at 0, 100, 200, and $300 \mathrm{~kg} \mathrm{ha}^{-1}$ were applied in stripes, and the eucalyptus biochar doses at $0,8,16$ and $32 \mathrm{Mg} \mathrm{ha}^{-1}$ were applied within the stripes, in a randomized block design. Sixteen treatments were used, with four replicates, in a total of 64 experimental plots. Each plot had nine rows, $10 \mathrm{~m}$ each, in a total of $40.5 \mathrm{~m}^{2}$ as plot area, of which $25.2 \mathrm{~m}^{2}$ were considered for the study.

Biochar was applied to the soil only once (in December, 2008), before planting, and it was incorporated into a $0-10 \mathrm{~cm}$ soil depth using a rotary hoe. This was the only occasion when the soil was physically moved. After that, the experiment was performed in no tillage system. Before incorporation into the soil, biochar was ground to pass through a $2 \mathrm{~mm}$ sieve. The elemental composition of it is presented in Table 1, and its molecular composition, determined by ${ }^{13} \mathrm{C}$-nuclear magnetic resonance, in Figure 2. In this spectrum, the presence of aryl groups (C-aryl, $130 \mathrm{ppm}$ ) - which are responsible for the stability of the material -, can be observed, as well as the presence also of phenolic carbon ( $\sim 150 \mathrm{ppm}$ ), which may be responsible for much of the original chemical reactivity of the biochar, due to the dissociable $-\mathrm{OH}$ groups.

The upland rice cultivar BRS Sertaneja was sown in January $8^{\text {th }}, 2009(2008 / 2009$, first year of the experiment) and in December 20 ${ }^{\text {th }}, 2009$ (2009/2010, second year of the experiment), by distributing $100 \mathrm{~kg} \mathrm{ha}^{-1}$ seeds, with $0.22 \mathrm{~m}$ spacing between rows and

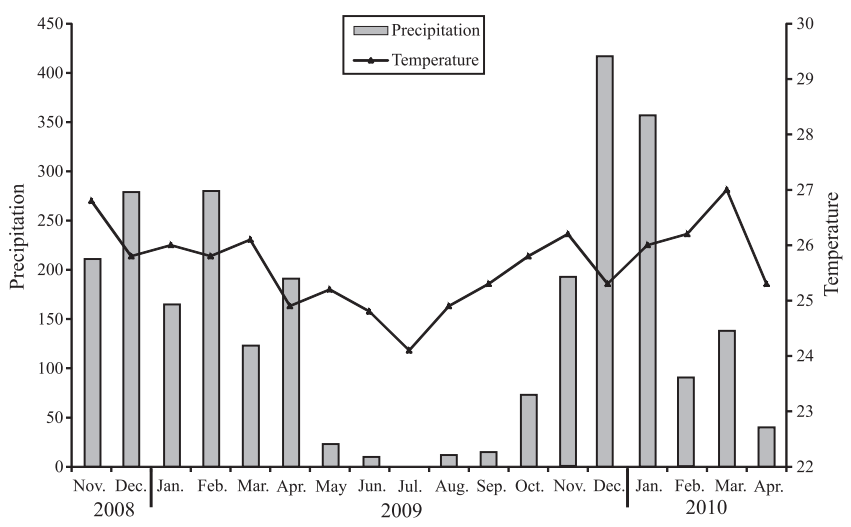

Figure 1. Precipitation ( $\mathrm{mm})$ and monthly average temperature $\left({ }^{\circ} \mathrm{C}\right)$ in Nova Xavantina, MT, Brazil, during the experimental period. Source: Instituto Nacional de Meteorologia, Experimental Station in Nova Xavantina, MT.

Table 1. Elemental composition (total $\mathrm{C}$ and $\mathrm{N}$ ) and extractable nutrients of the biochar used in the experiment.

\begin{tabular}{lc}
\hline Composition & Value \\
\hline Total C $\left(\mathrm{g} \mathrm{kg}^{-1}\right)$ & 774.0 \\
Total N $\left(\mathrm{g} \mathrm{kg}^{-1}\right)$ & 3.3 \\
Oxidizable C(1) $\left(\mathrm{g} \mathrm{kg}^{-1}\right)$ & 33.0 \\
$\mathrm{Ca}\left(\mathrm{cmol}_{\mathrm{c}} \mathrm{kg}^{-1}\right)$ & 2.8 \\
$\mathrm{Mg}\left(\mathrm{cmol}_{\mathrm{c}} \mathrm{kg}^{-1}\right)$ & 2.3 \\
$\mathrm{Al}\left(\mathrm{cmol}_{\mathrm{c}} \mathrm{kg}^{-1}\right)$ & 0.0 \\
$\mathrm{H}+\mathrm{Al}\left(\mathrm{cmol}_{\mathrm{c}} \mathrm{kg}^{-1}\right)$ & 0.0 \\
$\mathrm{P}\left(\mathrm{mg} \mathrm{dm}^{-3}\right)$ & 137.3 \\
$\mathrm{~K}\left(\mathrm{mg} \mathrm{dm}^{-3}\right)$ & 1937.3 \\
$\mathrm{Cu}\left(\mathrm{mg} \mathrm{dm}^{-3}\right)$ & 1.0 \\
$\mathrm{Fe}(\mathrm{mg} \mathrm{dm}$ & -3 \\
$\mathrm{Mn}\left(\mathrm{mg} \mathrm{dm}^{-3}\right)$ & 74.0 \\
$\mathrm{Zn}\left(\mathrm{mg} \mathrm{dm}^{-3}\right)$ & 88.0 \\
$\mathrm{C}: \mathrm{N} \mathrm{ratio}$ & 36.0 \\
\hline
\end{tabular}


1-3 cm sowing depth. Part of the chemical fertilizer was applied during the same operation. In the first year, the nitrogen doses $-0,15,32$ and $50 \mathrm{~kg} \mathrm{ha}^{-1}$ - were applied as urea at 30 days after sowing (DAS). Consequently, the total amount of $\mathrm{N}$ applied to the treatments was 0 , 20,42 and $65 \mathrm{~kg} \mathrm{ha}^{-1}$. In the second year, the equivalent of $55 \mathrm{~kg} \mathrm{ha}^{-1} \mathrm{~N}$ was applied to all plots. During the development of rice, the following phytosanitary care was taken: $241.8 \mathrm{~g} \mathrm{ha}^{-1}$ a.i. of 2,4-D was applied for weed control; $420 \mathrm{~g} \mathrm{ha}^{-1}$ methamidophos for pests; and $225 \mathrm{~g} \mathrm{ha}^{-1}$ tricyclazole (fungicide) for disease control.

The soil variables assessed were: $\mathrm{pH}$, determined using electrode method (Thomas, 1996); P, Ca, Mg and $\mathrm{K}$, extracted by diluted concentration of strong acids $\left(0.05 \mathrm{~mol} \mathrm{~L}^{-1} \mathrm{HCl}+0.0125 \mathrm{~mol} \mathrm{~L}^{-1} \mathrm{H}_{2} \mathrm{SO}_{4}\right.$; Mehlich I), as described by Kuo (1996). Phosphorus was determined by colorimetric method (Silva, 2009), $\mathrm{Ca}$ and $\mathrm{Mg}$ were determined by atomic spectroscopy, and $\mathrm{K}$ by flame emission spectrometry (Wright \& Stuczynski, 1996). Aluminum was extracted using

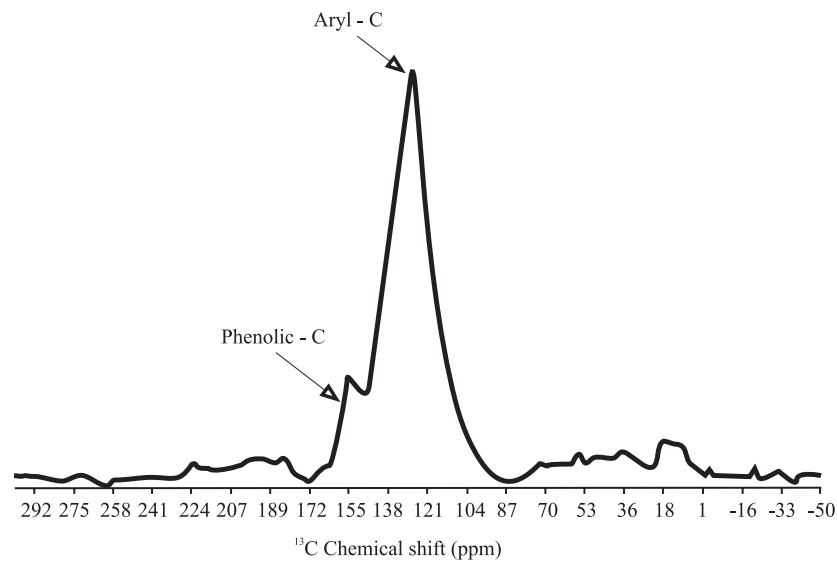

Figure 2. ${ }^{13} \mathrm{C}-\mathrm{NMR}$ spectrum of the eucalyptus biochar used in the experiment. The samples were analyzed by variable-amplitude cross-polarisation (VACP) solid-state ${ }^{13} \mathrm{C}$ nuclear magnetic resonance (NMR), in a $500 \mathrm{MHz}$ Varian spectrometer at ${ }^{13} \mathrm{C}$ and ${ }^{1} \mathrm{H}$ frequencies of 125 and $500 \mathrm{MHz}$, respectively. The experiments were carried out using a magic-angle spinning (MAS) of $14 \mathrm{kHz}$, a cross-polarisation time of $1 \mathrm{~ms}$, an acquisition time of $15 \mathrm{~ms}$, a recycle delay of $500 \mathrm{~ms}$ and high-power two-pulse phase-modulation (TPPM) proton decoupling of $70 \mathrm{kHz}$. The cross-polarisation time was chosen after variable contact time experiments, and the recycle delays in CP experiments were chosen to be five times longer than the longest ${ }^{1} \mathrm{H}$ spin-lattice relaxation time $\left(\mathrm{T}^{1} \mathrm{H}\right)$, as determined by inversion-recovery experiments. Spectra were processed with Gaussian apodization ( $\mathrm{gf}=0.004 \mathrm{secs}$ ). potassium chloride solution and titrated by sodium hydroxide, according to Bertsch \& Bloom (1996) modified by Silva (2009). Potential acidity $(\mathrm{H}+\mathrm{Al})$ was extracted by $0.5 \mathrm{~mol} \mathrm{~L}^{-1}$ calcium acetate solution at $\mathrm{pH} 7.1-7.2$, and titrated with $0.025 \mathrm{~mol} \mathrm{~L}^{-1} \mathrm{NaOH}$, using $10 \mathrm{~g} \mathrm{~L}^{-1}$ phenolphthalein as indicator according to Silva (2009). Cation exchange capacity was obtained through the sum of Ca, Mg and K (Faithfull, 2002). Soil texture was measured using a hydrometer method with a standard hydrometer which had the Bouyoucos scale (Gee \& Bauder, 1996), and the texture was identified as sandy loam. Base saturation ( $\mathrm{V} \%$ ) value was obtained using the following equation (Faithfull, 2002): $\mathrm{V}(\%)=100\left\{\left(\mathrm{Ca}^{2+}+\mathrm{Mg}^{2+}+\mathrm{K}^{+}\right)\left[\mathrm{Ca}^{2+}+\mathrm{Mg}^{2+}+\mathrm{K}^{+}+\left(\mathrm{H}^{+}+\mathrm{Al}^{3+}\right)\right]\right\}$. SOM was determined by the Walkley-Black method (Nelson \& Sommers, 1996), without external heating, using sulfuric acid to generate internal heat for the reaction.

Soil samples were collected at $0-10$ and $10-20 \mathrm{~cm}$ soil depth, during rice full flowering. Samples were composed by three subsamples, collected randomly within each plot. The original soil attributes were: $\mathrm{pH}$ $\mathrm{H}_{2} \mathrm{O}$, 5.6; P, $4.9 \mathrm{mg} \mathrm{dm}{ }^{-3} ; \mathrm{K}^{+}, 110.0 \mathrm{mg} \mathrm{dm}{ }^{-3} ; \mathrm{Ca}^{2+}$, $0.75 \mathrm{cmol}_{\mathrm{c}} \mathrm{dm}^{-3} ; \mathrm{Mg}^{2+}, 0.67 \mathrm{cmol}_{\mathrm{c}} \mathrm{dm}^{-3} ; \mathrm{Al}^{3+}, 0.15 \mathrm{cmol}_{\mathrm{c}}$ $\mathrm{dm}^{-3} ; \mathrm{H}^{+}+\mathrm{Al}^{3+}, 2.35 \mathrm{cmol}_{\mathrm{c}} \mathrm{dm}^{-3} ; \mathrm{V}, 41 \% ; \mathrm{CEC}$, $4.05 \mathrm{cmol}_{\mathrm{c}} \mathrm{dm}^{-3}$; SOM, $12.2 \mathrm{~g} \mathrm{~kg}^{-1}$; clay, $170 \mathrm{~g} \mathrm{~kg}^{-1}$; silt, $67 \mathrm{~g} \mathrm{~kg}^{-1}$; and sand, $763 \mathrm{~g} \mathrm{~kg}^{-1}$.

The effect of treatments on upland rice attributes was evaluated at 25, 40, 55 and 70 DAS. Dry matter accumulation (g per plant) was determined by collecting ten plants per plot; and the height $(\mathrm{cm})$ of 20 plants per plot was measured with the aid of a graduated tape. The dry matter mass was obtained by drying the plants at $65^{\circ} \mathrm{C}$, for 72 hours (Faithfull, 2002). Yield was evaluated with $14 \%$ grain humidity.

The generalized linear mixed model was adopted and accounted for the spatial autocorrelation among plots, by including rows and columns (coordinates of plots) as random effects. Thus, linear mixed models were fitted to investigate linear and quadratic effects of fertilizer, biochar and their interactions, treated as fixed effects. Analyses were performed using the SAS/ STAT mixed procedure (SAS Institute, 2000).

\section{Results and Discussion}

At $0-10 \mathrm{~cm}$ soil depth, there was a significant effect of biochar and of its interaction with fertilizer on total organic carbon (TOC, Tables 2 and 3), in both years. 
The positive effect of biochar on TOC levels was expected due to its high-carbon content (77.4\%). At $10-20 \mathrm{~cm}$ soil depth, in 2008/2009, a quadratic effect of the treatments on TOC was observed; however, the coefficient of determination $\left(\mathrm{R}^{2}=0.21\right)$ and the $\mathrm{F}$ were quite low. In 2009/2010, there was also a significant biochar effect and interaction at 10-20 cm depth, as it was observed at the $0-10 \mathrm{~cm}$ soil depth, in both years. The effect of biochar at this higher depth indicates the downward movement of TOC in the soil.

SOM was positively affected in the second year, at $0-10 \mathrm{~cm}$ soil depth, by biochar and fertilizer, but without a significant interaction between them (Tables 2 and 3). The effect of biochar on the SOM might have occurred due to its oxidizable $\mathrm{C}$ content (33.0 $\mathrm{g} \mathrm{kg}^{-1}$, Table 1). Zhang et al. (2012) also observed an increment of SOM levels under wheat straw biochar, on a paddy soil classified as Entic Hapludept planted with rice, in Jiangsu Province, China. At the $0-10 \mathrm{~cm}$ soil depth, the coefficient of determination was very low $\left(\mathrm{R}^{2}=0.09\right.$ and 0.11 in the first and second year, respectively), and the $\mathrm{F}$ value was also low, but significant.

Besides the macronutrients $\mathrm{P}$ and $\mathrm{Ca}$, biochar positively influenced soil acidity $(\mathrm{H}+\mathrm{Al}, \mathrm{Al}$ and pH) at 0-10 cm soil layer, in 2008/2009 (Table 2). Significant effect of biochar on the $\mathrm{P}$ availability was observed at $0-10 \mathrm{~cm}$ soil depth, featuring a faint linear behavior in the first year $\left(\mathrm{R}^{2}=0.13\right)$. The 32 $\mathrm{Mg} \mathrm{ha}^{-1}$ dose of biochar resulted in $17 \%$ increase in the availability of this element, compared to the control $\left(0 \mathrm{Mg} \mathrm{ha}^{-1}\right)$. These are consistent with data by Novak et al. (2009), who found $16 \%$ increase in $\mathrm{P}$ availability, at $0-10 \mathrm{~cm}$ soil depth, in a soil with $730 \mathrm{~g} \mathrm{~kg}^{-1}$ sand amended with biochar. These results, however, differ from those by Lehmann et al. (2003), in an Oxisol with lower sand content, in which carbon additions had no effect on $\mathrm{P}$ availability. The increased $\mathrm{P}$ availability due to biochar in very sandy soils, compared to soils of finer texture, may be related to the greater adsorption of $\mathrm{P}$ on soil solid phase with higher clay contents. According to Santos et al. (2008), in tropical and subtropical soils, oxides of $\mathrm{Fe}$ and $\mathrm{Al}$ are the main responsible for $\mathrm{P}$ adsorption to the mineral matrix of the soil.

Calcium levels in the soil also increased with biochar application $\left(\mathrm{R}^{2}=0.41\right)$, during the first year, at $0-10 \mathrm{~cm}$ soil depth (Table 2). The increase in $\mathrm{Ca}$ availability in the soil was of $36 \%$, when $32 \mathrm{Mg} \mathrm{ha}^{-1}$ biochar was applied, compared to the control (0 $\left.\mathrm{Mg} \mathrm{ha}^{-1}\right)$. Novak et al. (2009) also found positive effects of biochar addition on Ca levels in a sandy soil, as well as Steiner et al. (2007) and Van Zwieten et al.

Table 2. Effect of the eucalyptus biochar (C) and NPK fertilization (N) on soil chemical attributes at 0-10 and 10-20 cm soil depths, in 2008/2009.

\begin{tabular}{|c|c|c|c|c|}
\hline Parameter & Equation & $\mathrm{R}^{2}$ & $\mathrm{~F}$ & $\mathrm{p}$ \\
\hline \multicolumn{5}{|c|}{$0-10 \mathrm{~cm}$ soil depth } \\
\hline $\mathrm{pH}$ & $5.77+0.01 C^{*}$ & 0.48 & 56.68 & 0.0001 \\
\hline $\mathrm{Ca}$ & $0.75+0.009 C^{*}$ & 0.41 & 42.62 & 0.0001 \\
\hline $\mathrm{Mg}$ & $0.69-0.0004 \mathrm{~N}-0.001 \mathrm{C}+0.0000007 \mathrm{~N}^{2}+0.00005 \mathrm{C}^{2}+0.000006 \mathrm{NC}$ & 0.14 & 1.88 & 0.1100 \\
\hline $\mathrm{Al}$ & $0.16-0.0006 \mathrm{~N}^{*}-0.006 \mathrm{C}^{*}+0.000001 \mathrm{~N}^{2}+0.0001 \mathrm{C}^{2}+0.000004 \mathrm{NC}$ & 0.40 & 7.75 & 0.0001 \\
\hline $\mathrm{H}+\mathrm{Al}$ & $2.38+0.00002 \mathrm{~N}-0.02 \mathrm{C}^{*}-0.000003 \mathrm{~N}^{2}+0.0002 \mathrm{C}^{2 * 0.00001 \mathrm{NC}}$ & 0.42 & 8.48 & 0.0001 \\
\hline $\mathrm{P}$ & $6.45+0.09 C^{*}$ & 0.13 & 9.26 & 0.0030 \\
\hline $\mathrm{K}$ & $105.59-0.18 \mathrm{~N}^{*}+0.86 \mathrm{C}+0.0007 \mathrm{~N}^{2 *}+0.01 \mathrm{C}^{2}-0.001 \mathrm{NC}$ & 0.40 & 7.69 & 0.0001 \\
\hline TOC & $1.22+0.00004 \mathrm{~N}-0.06 \mathrm{C}-0.000002 \mathrm{~N}^{2}+0.003 \mathrm{C}^{2 *}+0.0002 \mathrm{NC}^{*}$ & 0.47 & 8.07 & 0.0001 \\
\hline SOM & $14.05+0.004 \mathrm{~N}+0.002 \mathrm{C}-0.00001 \mathrm{~N}^{2 *}+0.0002 \mathrm{C}^{2}+0.00002 \mathrm{NC}$ & 0.14 & 1.93 & 0.1000 \\
\hline \multicolumn{5}{|c|}{ 10-20 cm soil depth } \\
\hline $\mathrm{pH}$ & $5.61+0.0004 \mathrm{~N}+0.003 \mathrm{C}+0.000003 \mathrm{~N}^{2}+0.00005 \mathrm{C}^{2}+0.0000009 \mathrm{NC}$ & 0.41 & 8.12 & 0.0001 \\
\hline $\mathrm{Ca}$ & $0.74-0.04 \mathrm{C}$ & 0.04 & 2.85 & 0.0900 \\
\hline $\mathrm{Mg}$ & $0.59-0.00005 \mathrm{~N}^{*}-0.003 \mathrm{C}+0.000002 \mathrm{~N}^{2 *}+0.00008 \mathrm{C}^{2}-0.000002 \mathrm{NC}$ & 0.13 & 1.77 & 0.1300 \\
\hline Al & $0.17+0.0003 \mathrm{~N}-0.0002 \mathrm{C}-0.000002 \mathrm{~N}^{2}-0.00003 \mathrm{C}^{2}-0.000002 \mathrm{NC}$ & 0.21 & 3.03 & 0.0200 \\
\hline $\mathrm{H}+\mathrm{Al}$ & $2.31-0.002 \mathrm{~N}-0.005 \mathrm{C}+0.000002 \mathrm{~N}^{2}-0.00002 \mathrm{C}^{2}+0.000005 \mathrm{NC}$ & 0.21 & 3.11 & 0.0200 \\
\hline $\mathrm{P}$ & $4.29+0.06 \mathrm{~N}+0.04 \mathrm{C}+0.000004 \mathrm{~N}^{2}-0.0002 \mathrm{C}^{2}-0.00005 \mathrm{NC}$ & 0.30 & 4.86 & 0.0009 \\
\hline $\mathrm{K}$ & $100.79-0.11 \mathrm{~N}+0.91 \mathrm{C}+0.0005 \mathrm{~N}^{2 *}-0.002 \mathrm{C}^{2}-0.002 \mathrm{NC}$ & 0.19 & 2.67 & 0.0300 \\
\hline TOC & $1.03+0.004 \mathrm{~N}-0.04 \mathrm{C}-0.000009 \mathrm{~N}^{2}+0.001 \mathrm{C}^{2}+0.00003 \mathrm{NC}$ & 0.21 & 2.36 & 0.0500 \\
\hline SOM & $10.66+0.05 C^{*}-0.002 C^{2 *}$ & 0.09 & 2.96 & 0.0500 \\
\hline
\end{tabular}

*Significant at 5\% probability; TOC, total organic carbon; SOM, soil organic matter. 
(2010), who investigated the combined use of charcoal and fertilizer.

However, the effect of the biochar was not observed for $\mathrm{P}$ or $\mathrm{Ca}$ in the 10-20 cm layer (Table 2). This was expected because there was no biochar incorporation at this layer.

In the second year (Table 3), the biochar had a reduced effect, or its residual effect was overcome by the effect of the fertilizer, as the fertilizer was applied annually, and the charcoal only once at the beginning of the experiment.

The largest positive effect of the biochar occurred on the chemical reaction of the soil $\left(\mathrm{R}^{2}=0.48\right)$, at 0-10 cm layer, in the first year (Table 2). The $\mathrm{pH}$ increased with increasing doses of biochar. Similar results were obtained by Lehmann et al. (2003), who observed a reduction on acidity by $0.75 \mathrm{pH}$ units (from 5.14 to 5.89 ) with the addition of $20 \%$ biochar in an Oxisol. In the first year, the potential acidity $(\mathrm{H}+\mathrm{Al})$ was reduced $\left(\mathrm{R}^{2}=0.42\right)$ by nearly $20 \%$ with $32 \mathrm{Mg} \mathrm{ha}^{-1}$ biochar, at $0-10 \mathrm{~cm}$ soil depth, in comparison to the control. At $10-20 \mathrm{~cm}$ soil layer, as expected, the effect of the treatments was smaller. These results corroborate those obtained by Mbagwu \& Piccolo (1997) and by Topoliantz et al. (2005), who found lower levels of $\mathrm{H}+\mathrm{Al}$ with the use of charcoal.

In the second year, there was no effect of the treatments on $\mathrm{pH}$ or $\mathrm{H}+\mathrm{Al}$ parameters (Table 3).

The effect of biochar on available $\mathrm{K}$ was not observed in the first year (Table 2), in neither of the depths. This parameter was far more dependent on the application of the fertilizer. In the second year (Table 3 ), however, at 10-20 cm soil depth, the biochar increased available $\mathrm{K}$ levels, although with a low coefficient of determination $\left(\mathrm{R}^{2}=0.22\right)$. An explanation might be the downward movement of part of the finely ground $(\leq 2 \mathrm{~mm}$ ) biochar into the $10-20 \mathrm{~cm}$ soil layer, as it was discussed for TOC levels. Another explanation is that, in that layer, the effect of the fertilizer was lower, since it was placed at around 3 to $5 \mathrm{~cm}$ depth at sowing, and, therefore, the effect of biochar on $\mathrm{K}$ availability might have become observable. The biochar contains reasonable amounts of $\mathrm{K}, \mathrm{P}$ and $\mathrm{Ca}$, besides high levels of organic C (Table 1).

The treatments had no effect on available $\mathrm{Mg}$, except for the second year at $0-10 \mathrm{~cm}$ soil depth (Table 3).

The application of biochar and fertilizer had a greater effect on plant physiological parameters (Table 4) than on the soil fertility ones. In the first year,

Table 3. Effect of the eucalyptus biochar (C) and NPK fertilization (N) on soil chemical attributes at 0-10 and 10-20 cm soil depths, in 2009/2010.

\begin{tabular}{|c|c|c|c|c|}
\hline Parameter & Equation & $\mathrm{R}^{2}$ & $\mathrm{~F}$ & $\mathrm{p}$ \\
\hline \multicolumn{5}{|c|}{$0-10 \mathrm{~cm}$ soil depth } \\
\hline $\mathrm{pH}$ & $5.19+0.001 \mathrm{~N}^{*}+0.003 \mathrm{C}-0.000001 \mathrm{~N}^{2}+0.00001 \mathrm{C}^{2}+0.00000009 \mathrm{NC}$ & 0.36 & 6.59 & 0.0001 \\
\hline $\mathrm{Ca}$ & $6.92+0.009 \mathrm{~N}-0.06 \mathrm{C}-0.00003 \mathrm{~N}^{2}+0.003 \mathrm{C}^{2}+0.0002 \mathrm{NC}$ & 0.35 & 6.37 & 0.0001 \\
\hline $\mathrm{Mg}$ & $5.80+0.006 \mathrm{~N}-0.05 \mathrm{C}-0.00001 \mathrm{~N}^{2}+0.002 \mathrm{C}^{2}+0.0002 \mathrm{NC}$ & 0.36 & 6.47 & 0.0001 \\
\hline $\mathrm{Al}$ & $2.35+0.0004 \mathrm{~N}-0.008 \mathrm{C}-0.000002 \mathrm{~N}^{2}+0.0002 \mathrm{C}^{2}-0.00009 \mathrm{NC}$ & 0.09 & 1.11 & 0.3600 \\
\hline $\mathrm{H}+\mathrm{Al}$ & $25.99-0.05 \mathrm{C}$ & 0.02 & 1.02 & 0.3200 \\
\hline $\mathrm{P}$ & $7.75+0.05 \mathrm{~N}^{*}+0.14 \mathrm{C}-0.00006 \mathrm{~N}^{2}-0.004 \mathrm{C}^{2}+0.0003 \mathrm{NC}$ & 0.59 & 16.38 & 0.0001 \\
\hline K & $91.3+0.42 \mathrm{C}$ & 0.05 & 3.28 & 0.0700 \\
\hline $\mathrm{Zn}$ & $11.32-0.03 \mathrm{~N}+0.19+0.00006 \mathrm{~N}^{2}-0.005 \mathrm{C}^{2}-0.0002 \mathrm{NC}$ & 0.07 & 0.85 & 0.5200 \\
\hline TOC & $1.01+0.002 \mathrm{~N}+0.05 \mathrm{C}^{*}-0.000003 \mathrm{~N}^{2}-0.0005 \mathrm{C}^{2}-0.00009 \mathrm{NC} *$ & 0.40 & 7.69 & 0.0001 \\
\hline SOM & $7.97+0.01 \mathrm{~N}^{*}-0.09 \mathrm{C}^{*}-0.00003 \mathrm{~N}^{2 *}+0.003 \mathrm{C}^{2 *}+0.000004 \mathrm{NC}$ & 0.38 & 7.19 & 0.0001 \\
\hline \multicolumn{5}{|c|}{$10-20 \mathrm{~cm}$ soil depth } \\
\hline $\mathrm{pH}$ & $5.32+0.001 \mathrm{~N}+0.03 \mathrm{C}-0.0000009 \mathrm{~N}^{2}+0.00004 \mathrm{C}^{2}+0.0000005 \mathrm{NC}$ & 0.33 & 5.77 & 0.0002 \\
\hline $\mathrm{Ca}$ & $8.04-0.007 \mathrm{~N}-0.08 \mathrm{C}+0.000009 \mathrm{~N}^{2}+0.003 \mathrm{C}^{2}+0.0002 \mathrm{NC}$ & 0.09 & 1.16 & 0.3400 \\
\hline $\mathrm{Mg}$ & $6.05-0.004 \mathrm{~N}-0.008 \mathrm{C}+0.00002 \mathrm{~N}^{2}+0.0004 \mathrm{C}^{2}+0.0001 \mathrm{NC}$ & 0.09 & 1.21 & 0.3200 \\
\hline $\mathrm{Al}$ & $2.46+0.002 \mathrm{~N}-0.008 \mathrm{C}-0.00001 \mathrm{~N}^{2}-0.0002 \mathrm{C}^{2}+0.00002 \mathrm{NC}$ & 0.03 & 0.37 & 0.8700 \\
\hline $\mathrm{H}+\mathrm{Al}$ & $25.74-0.04 \mathrm{C}$ & 0.01 & 0.66 & 0.4200 \\
\hline $\mathrm{P}$ & $6.83+0.01 \mathrm{~N}+0.01 \mathrm{C}+0.00001 \mathrm{~N}^{2}+0.0003 \mathrm{C}^{2}-0.00001 \mathrm{NC}$ & 0.49 & 11.20 & 0.0001 \\
\hline K & $110.34-0.94 \mathrm{C}+0.05 \mathrm{C}^{2 *}$ & 0.22 & 8.37 & 0.0006 \\
\hline $\mathrm{Zn}$ & $25.97-0.04 \mathrm{~N}-0.24 \mathrm{C}+0.00005 \mathrm{~N}^{2}+0.007 \mathrm{C}^{2}-0.00004 \mathrm{NC}$ & 0.10 & 1.25 & 0.2900 \\
\hline TOC & $0.9+0.001 \mathrm{~N}+0.03 \mathrm{C}^{*}-0.0000007 \mathrm{~N}^{2}-0.00007 \mathrm{C}^{2}-0.0001 \mathrm{NC}^{*}$ & 0.29 & 4.71 & 0.0010 \\
\hline SOM & $6.68+0.01 \mathrm{~N}+0.008 \mathrm{C}-0.00002 \mathrm{~N}^{2}+0.0005 \mathrm{C}^{2}-0.0001 \mathrm{NC}$ & 0.11 & 1.50 & 0.2000 \\
\hline
\end{tabular}

*Significant at $5 \%$ of probability; TOC, total organic carbon; SOM, soil organic matter. 
Table 4. Effect of the eucalyptus biochar (C) and NPK fertilization (N) on upland rice attributes measured in 2008/2009 and 2009/2010.

\begin{tabular}{|c|c|c|c|c|}
\hline Parameter & Equation & $\mathrm{R}^{2}$ & $\mathrm{~F}$ & $\mathrm{p}$ \\
\hline \multicolumn{5}{|c|}{$2008 / 2009$} \\
\hline Height at 22 DAS & $25.02+0.07 \mathrm{~N}^{*}+0.08 \mathrm{C}-0.0001 \mathrm{~N}^{2 *}-0.0004 \mathrm{C}^{2}-0.0005 \mathrm{NC}^{*}$ & 0.74 & 32.80 & 0.0001 \\
\hline Height at 40 DAS & $54.87+0.04 \mathrm{~N}^{*}-0.11 \mathrm{C}-0.00007 \mathrm{~N}^{2}+0.002 \mathrm{C}^{2}-0.0001 \mathrm{NC}$ & 0.29 & 4.73 & 0.0010 \\
\hline Height at 55 DAS & $60.10+0.08 \mathrm{~N}^{*}-0.05 \mathrm{C}-0.00008 \mathrm{~N}^{2}+0.006 \mathrm{C}^{2}-0.001 \mathrm{NC}^{*}$ & 0.71 & 28.66 & 0.0001 \\
\hline Height at 70 DAS & $61.30+0.11 \mathrm{~N}^{*}+0.009 \mathrm{C}-0.0002 \mathrm{~N}^{2} *+0.002 \mathrm{C}^{2}-0.0007 \mathrm{NC}$ & 0.83 & 57.12 & 0.0001 \\
\hline Dry matter at 22 DAS & $1.67+0.004 \mathrm{~N}^{*}-0.02 \mathrm{C}-0.000005 \mathrm{~N}^{2}+0.0005 \mathrm{C}^{2}-0.00005 \mathrm{NC}$ & 0.57 & 15.22 & 0.0001 \\
\hline Dry matter at 40 DAS & $3.74+0.005 \mathrm{~N}+0.04 \mathrm{C}+0.00003 \mathrm{~N}^{2} *-0.001 \mathrm{C}^{2}-0.0001 \mathrm{NC}$ & 0.65 & 21.65 & 0.0001 \\
\hline Dry matter at55 DAS & $15.39-0.04 \mathrm{~N}^{*}-0.05 \mathrm{C}+0.0001 \mathrm{~N}^{2 *}+0.001 \mathrm{C}^{2}-0.0002 \mathrm{NC}$ & 0.34 & 6.03 & 0.0001 \\
\hline Dry matter at70 DAS & $18.56+0.03 \mathrm{~N}^{*}-0.05 \mathrm{C}-0.00008 \mathrm{~N}^{2 *}+0.0005 \mathrm{C}^{2}-0.00004 \mathrm{NC}$ & 0.17 & 2.36 & 0.0500 \\
\hline Yield & $498.45+22.55 C^{*}-0.16 C^{2}$ & 0.77 & 104.50 & 0.0001 \\
\hline \multicolumn{5}{|c|}{$2009 / 2010$} \\
\hline Height at 22 DAS & $19.17+0.03 \mathrm{~N}^{*}+0.24 \mathrm{C}^{*}-0.00004 \mathrm{~N}^{2}-0.003 \mathrm{C}^{2}-0.0003 \mathrm{NC}$ & 0.44 & 8.94 & 0.0001 \\
\hline Height at 40 DAS & $46.9+0.11 \mathrm{~N}^{*}+0.04 \mathrm{C}-0.0002 \mathrm{~N}^{2} *+0.001 \mathrm{C}^{2}-0.00005 \mathrm{NC}$ & 0.63 & 19.84 & 0.0001 \\
\hline Height at 55 DAS & $51.33+0.18 \mathrm{~N}^{*}+0.23 \mathrm{C}-0.0004 \mathrm{~N}^{2 *}-0.006 \mathrm{C}^{2}+0.00005 \mathrm{NC}$ & 0.81 & 48.14 & 0.0001 \\
\hline Height at 70 DAS & $76.27+0.05 \mathrm{~N}^{*}+0.09 \mathrm{C}-0.0002 \mathrm{~N}^{2} *-0.002 \mathrm{C}^{2}+0.0005 \mathrm{C}$ & 0.31 & 5.31 & 0.0004 \\
\hline Dry matter at 22 DAS & $0.78+0.005 \mathrm{~N}^{*}+0.0002 \mathrm{C}-0.00001 \mathrm{~N}^{2 *}+0.00007 \mathrm{C}^{2}+0.00003 \mathrm{NC}^{*}$ & 0.71 & 28.12 & 0.0001 \\
\hline Dry matter at40 DAS & $4.13+0.03 \mathrm{~N}^{*}+0.04 \mathrm{C}-0.00008 \mathrm{~N}^{2}-0.0007 \mathrm{C}^{2}+0.00001 \mathrm{NC}$ & 0.59 & 16.35 & 0.0001 \\
\hline Dry matter at 55 DAS & $6.72+0.05 \mathrm{~N}^{*}+0.12 \mathrm{C}^{*}-0.0001 \mathrm{~N}^{2 *}-0.001 \mathrm{C}^{2}-0.00001 \mathrm{NC}$ & 0.66 & 22.89 & 0.0001 \\
\hline Dry matter at 70 DAS & $17.87+0.03 \mathrm{~N}+0.29 \mathrm{C}-0.00007 \mathrm{~N}^{2}-0.008 \mathrm{C}^{2}-0.00008 \mathrm{NC}$ & 0.13 & 1.80 & 0.1300 \\
\hline Yield & $453.42+0.56 \mathrm{~N}+17.96 \mathrm{C}^{*}-0.002 \mathrm{~N}^{2}-0.1 \mathrm{C}^{2}+0.02 \mathrm{NC}^{*}$ & 0.84 & 60.84 & 0.0001 \\
\hline
\end{tabular}

*Significant at $5 \%$ probability; DAS, days after sowing.

biochar had a linear effect on the rice yield $\left(\mathrm{R}^{2}=0.77\right)$, and a nonsignificant interaction with the fertilizer. In the second year, however, there was an interaction between the biochar and the fertilizer in their effect for the yield. A similar effect was reported by Steiner et al. (2007), who found an increment in upland rice yield in Manaus, when charcoal and mineral fertilizer were applied together, and by Zhang et al. (2012), in paddy-field rice. There are several reports on the positive effect of the biochar on the yield of different crops. Oguntunde et al. (2004) observed an increase of over 91 and $278 \%$ for charcoal and charcoal + mineral fertilizer, respectively, on corn yield. Nevertheless, plant growth and dry matter accumulation were affected mainly by the application of the fertilizer.

Dry matter accumulation was not affected by the biochar (Table 4) during the first year. However, in the second year, a positive interaction was found for this parameter at 22 DAS. Madari et al. (2006) observed an increase in the height and dry matter biomass of rice cultivar BRS Primavera in the early stage (until 28 DAS) of crop development with the application of $21 \mathrm{Mg} \mathrm{ha}^{-1}$ biochar, in a clay soil, in a pot experiment. Nehls (2002) reported a 100 to $320 \%$ increase in the dry matter biomass of rice with the application of more than $14 \mathrm{Mg} \mathrm{ha}^{-1}$ biochar.

As there was no correlation between the soil nutrient levels and plant growth or yield, probably there were other ways of biochar affecting rice yield. The increased water retention provoked by the addition of biochar to the soil, especially in coarse textured soils, like the one studied hereby, was reported by Sohi et al. (2010) and Karhu et al. (2011). Additionally, Pereira et al. (2012) reported that biochar positively affected the amount of plant available soil water. This effect of biochar may also have contributed to its positive effect on yield.

\section{Conclusions}

1. Eucalyptus biochar improves the fertility properties of sandy loam soil, with a largest effect in the surface soil layer and in the first year after its incorporation.

2. Eucalyptus biochar has a low residual effect on soil chemical attributes.

3 . For growth and dry matter accumulation of upland rice, the eucalyptus biochar starts to have a positive 
combined effect with the fertilizer in the second year, at the early stage of plant development.

4. Eucalyptus biochar positively affects upland rice yields since the first year of its application.

\section{Acknowledgements}

To Conselho Nacional de Desenvolvimento Científico e Tecnológico, for financial support and fellowship; to Embrapa, for financial and technical support; and to Centro Brasileiro de Pesquisas Físicas for the NMR analysis.

\section{References}

BARRETO, R.C.; MADARI, B.E.; MADDOCK, J.E.L.; MACHADO, P.L.O.A.; TORRES, E.; FRANCHINI, J.; COSTA, A.R. The impact of soil management on aggregation, carbon stabilization and carbon loss as $\mathrm{CO}_{2}$ in the surface layer of a Rhodic Ferralsol in Southern Brazil. Agriculture, Ecosystems and Environment, v.132, p.243-251, 2009.

BERTSCH, P.M.; BLOOM, P.R. Aluminum. In: SPARKS, D.L; PAGE, A.L.; HELMKE, P.A.; LOEPPERT, R.H.; SOLTANPOUR, P.N.; TABATABAI, M.A.; JOHNSTON, C.T.; SUMNER, M.E. (Ed.). Methods of soil analysis. Part 3. Chemical methods. Madison: Soil Science Society of America, 1996. p.517-550. (Soil Science Society of America book series, 5).

BOER, C.A.; ASSIS, R.L. de; SILVA, G.P.; BRAZ, A.J.B.P.; BARROSO, A.L. de L.; CARGNELUTTI FILHO, A.; PIRES, F.R. Ciclagem de nutrientes por plantas de cobertura na entressafra em um solo de cerrado. Pesquisa Agropecuária Brasileira, v.42, p.1269-1276, 2007.

CARPIM, L.K.; ASSIS, R.L. de; BRAZ, A.J.B.P.; SILVA, G.P.; PIRES, F.R.; PEREIRA, V.C.; GOMES, G.V.; SILVA, A.G. da. Liberação de nutrientes pela palhada de milheto em diferentes estádios fenológicos. Revista Brasileira de Ciência do Solo, v.32, p.2813-2819, 2008.

CRUSCIOL, C.A.C.; COTTICA, R.L.; LIMA, E. do V.; ANDREOTTI, M.; MORO, E.; MARCON, E. Persistência de palhada e liberação de nutrientes do nabo forrageiro no plantio direto. Pesquisa Agropecuária Brasileira, v.40, p.161-168, 2005.

FAGERIA, N.K.; SOUZA, N.P. de. Resposta das culturas de arroz e feijão em sucessão à adubação em solo de cerrado. Pesquisa Agropecuária Brasileira, v.30, p.359-368, 1995.

FAITHFULL, N.T. Methods in agricultural chemical analysis: a pratical handbook. Oxon: CABI, 2002. 206p.

GEE, G.W.; BAUDER, J.W. Particle-size analysis. In: SPARKS, D.L.; PAGE, A.L.; HELMKE, P.A.; LOEPPERT, R.H.; SOLTANPOUR, P.N.; TABATABAI, M.A.; JOHNSTON, C.T.; SUMNER, M.E. (Ed.). Methods of soil analysis. Part 3. Chemical methods. Madison: Soil Science Society of America, 1996. p.383-411. (Soil Science Society of America book series, 5).
GLASER, B.; LEHMANN, J.; ZECH, W. Ameliorating physical and chemical properties of highly weathered soil in the tropics with charcoal - a review. Biology and Fertility of Soils, v.35, p.219-230, 2002.

KARHU, K.; MATTILA, T.; BERGSTRÖM, I.; REGINA, K. Biochar addition to agricultural soil increased $\mathrm{CH}_{4}$ uptake and water holding capacity - results from a short-term pilot field study. Agriculture, Ecosystems and Environment, v.140, p.309-313, 2011.

KOOKANA, R.S.; SARMAH, A.K.; VAN ZWIETEN L. Biochar application to soil: agronomic and environmental benefits and unintended consequences. Advances in Agronomy, v.112, p.103-143, 2011.

KUO, S. Phosphorus. In: SPARKS, D.L.; PAGE, A.L.; HELMKE, P.A.; LOEPPERT, R.H.; SOLTANPOUR, P.N.; TABATABAI, M.A.; JOHNSTON, C.T.; SUMNER, M.E. (Ed.). Methods of soil analysis. Part 3. Chemical methods. Madison: Soil Science Society of America, 1996. p.869-919. (Soil Science Society of America book series, 5).

LEHMANN, J.; SILVA, J.P. da; STEINER, C.; NEHLS, T.; ZECH, W.; GLASER, B. Nutrient availability and leaching in an archaeological Anthrosol and a Ferralsol of the Central Amazon basin: fertilizer, manure and charcoal amendments. Plant and Soil, v.249, p.343-357, 2003.

LOEPPERT, R.H.; INSKEEP, W.P. Iron. In: SPARKS, D.L.; PAGE, A.L.; HELMKE, P.A.; LOEPPERT, R.H.; SOLTANPOUR, P.N.; TABATABAI, M.A.; JOHNSTON, C.T.; SUMNER, M.E. (Ed.). Methods of soil analysis. Part 3. Chemical methods. Madison: Soil Science Society of America, 1996. p. 639-664. (Soil Science Society of America book series, 5).

MADARI, B.E.; COSTA, A.R. da; CASTRO, L.M. de; SANTOS, J.L.S.; BENITES, V. de M.; ROCHA, A. de O.; MACHADO, P.L.O. de A. Carvão vegetal como condicionador de solo para arroz de terras altas (cultivar Primavera): um estudo prospectivo. Santo Antônio de Goiás: Embrapa Arroz e Feijão, 2006. 6p. (Embrapa Arroz e Feijão. Comunicado técnico, 125).

MBAGWU, J.S.C.; PICCOLO, A. Effects of humic substances from oxidized coal on soil chemical properties and maize yield. In: DROZD, J.; GONET, S.S.; SENESI, N.; WEBER, J. (Ed.). The role of humic substances in the ecosystems and in environmental protection. Wroclaw: International Humic Substances Society, 1997. p.921-925.

NACHTERGAELE, F.O. Classification systems: FAO. In: HILLEL, D. (Ed.). Encyclopedia of soils in the environment. Oxford: Elsevier, 2005. p.216-222.

NEHLS, T. Fertility improvement of a Terra Firme Oxisol in central Amazonia by charcoal applications. 2002. 60p. Thesis (Magister) - University of Bayreuth, Bayreuth.

NELSON, D.W.; SOMMERS, L.E. Total carbon, organic carbon and organic matter. In: SPARKS, D.L.; PAGE, A.L.; HELMKE, P.A.; LOEPPERT, R.H.; SOLTANPOUR, P.N.; TABATABAI, M.A.; JOHNSTON, C.T.; SUMNER, M.E. (Ed.). Methods of soil analysis. Part 3. Chemical methods. Madison: Soil Science Society of America, 1996. p.961-1010. (Soil Science Society of America book series, 5). 
NOVAK, J.M.; BUSSCHER, W.J.; LAIRD, D.L.; AHMEDNA, M.; WATTS, D.W.; NIANDOU, A.S. Impact of biochar amendment on fertility of a southeastern Coastal Plain soil. Soil Science, v.174, p.105-112, 2009.

OGUNTUNDE, P.G.; FOSU, M.; AJAYI, A.E.; GIESEN, N.V. Effects of charcoal production on maize yield, chemical properties and texture of soil. Biology and Fertility of Soils, v.39, p.296-299, 2004 .

PEREIRA, R.G.; HEINEMANN, A.B.; MADARI, B.E.; CARVALHO, M.T. de M.; KLIEMANN, H.J.; SANTOS, A.P. dos. Transpiration response of upland rice to water deficit changed by different levels of eucalyptus char. Pesquisa Agropecuária Brasileira, v.47, p.716-721, 2012.

SANTOS, A.B. dos; SILVA, O.F. da; FERREIRA, E. Avaliação de práticas culturais em um sistema agrícola irrigado por aspersão. Pesquisa Agropecuária Brasileira, v.32, p.317-327, 1997.

SANTOS, D.R. dos; GATIBONI, L.C.; KAMINSKI, J. Fatores que afetam a disponibilidade do fósforo e o manejo da adubação fosfatada em solos sob sitema plantio direto. Ciência Rural, v.38, p.576-586, 2008.

SAS INSTITUTE. SAS/STAT user's guide. Version 8. Cary: SAS Institute, 2000. 3809p.

SILVA, F.C. da. Manual de análises químicas de solos, plantas e fertilizantes. 2.ed. Brasília: Embrapa Informação Tecnológica; Rio de Janeiro: Embrapa Solos, 2009. 627p.

SOHI, S.P.; KRULL, E.; LOPEZ-CAPEL, E.; BOL, R. A review of biochar and its use and function in soil. Advances in Agronomy, v.105, p.47-82, 2010.

STEINER, C.; TEIXEIRA, W.G.; LEHMANN, J.; NEHLS, T.; MACÊDO, J.L.V. de; BLUM, W.E.H.; ZECH, W. Long term effects of manure, charcoal and mineral fertilization on crop production and fertility on a highly weathered Central Amazonian upland soil. Plant and Soil, v.291, p.275-290, 2007.

THOMAS, G.W. Soil $\mathrm{pH}$ and Soil acidity. In: PAGE, A.L.; HELMKE, P.A.; LOEPPERT, R.H.; SOLTANPOUR, P.N.; TABATABAI, M.A.; JOHNSTON, C.T.; SUMNER, M.E. (Ed.). Methods of soil analysis. Part 3. Chemical methods. Madison: Soil Science Society of America, 1996. p.475-490. (Soil Science Society of America book series, 5).

TOPOLIANTZ, S.; PONGE, J.F.; BALLOF, S. Manioc peel and charcoal: a potential organic amendment for sustainable soil fertility in the tropics. Biology and Fertility of Soils, v.41, p.15-21, 2005.

TORRES, J.L.R.; PEREIRA, M.G.; ANDRIOLI, I.; POLIDORO, J.C.; FABIAN, A.J. Decomposição e liberação de nitrogênio de resíduos culturais de plantas de cobertura em um solo de cerrado. Revista Brasileira de Ciência do Solo, v.29, p.609-618, 2005.

VAN ZWIETEN, L.; KIMBER, S.; MORRIS, S.; CHAN, K.Y.; DOWNIE, A.; RUST, J.; JOSEPH, S.; COWIE, A. Effects of biochar from slow pyrolysis of papermill waste on agronomic performance and soil fertility. Plant and Soil, v.27, p.235-246, 2010.

WRIGHT, R.J.; STUCZYNSKI, T. Atomic absorption and flame emission spectrometry. In: SPARKS, D.L.; PAGE, A.L.; HELMKE, P.A.; LOEPPERT, R.H.; SOLTANPOUR, P.N.; TABATABAI, M.A.; JOHNSTON, C.T.; SUMNER, M.E. (Ed.). Methods of soil analysis. Part 3. Chemical methods. Madison: Soil Science Society of America, 1996. p.65-90. (Soil Science Society of America book series, 5).

ZHANG, A.; BIAN, R.; PAN, G.X.; CUI, L.Q.; HUSSAIN, Q.; LI, L.Q.; ZHENG, J.W.; ZHENG, J.F.; ZHANG, X.H.; HAN, X.J.; YU, X.Y. Effects of biochar amendment on soil quality, crop yield and greenhouse gas emission in a Chinese rice paddy: a field study of 2 consecutive rice growing cycles. Field Crops Research, v.127, p.153-160, 2012.

Received on January 31, 2011 and accepted on April 12, 2012

Pesq. agropec. bras., Brasília, v.47, n.5, p.699-706, maio 2012 